DOI:

\title{
FAKTOR YANG MEMPENGARUHI KEPATUHAN PENGOBATAN PENDERITA HIPERTENSI USIA PRODUKTIF DI DESA KARANGSONO KECAMATAN BARAT KABUPATEN MAGETAN
}

\author{
Dara Aprilia Aurilita Mawanti, Avicena Sakufa Marsanti, Hanifah Ardiani ${ }^{1}$ \\ ${ }^{1}$ STIKES Bhakti Husada Mulia Madiun, Fakultas Kesehatan Masyarakat, Jl. Taman Praja \\ No.25 Mojorejo, Kecamatan Taman, Kota Madiun, Jawa Timur, 63139 \\ E-mail: daraaprilia34@gmail.com
}

\section{FACTORS AFFECTING THE MEDICATION COMPLIANCE OF HYPERTENSION PATIENTS AT PRODUCTIVE AGE IN KARANGSONO VILLAGE, BARAT SUB-DISTRICT MAGETAN DISTRICT}

\begin{abstract}
Background : In 2018, Karangsono Village is village with the highest number of medication incompliance by hypertension patients at productive age reaching 70,7\% compared to other 8 villages in Tebon Health Center working area. Objective : This research for to analyze factors affecting the medication compliance of hypertension patients at productive age and factor which affects the medication compliance the most. Method: This research was done through case control design with the research samples included 58 chosen using simple random sampling. The data was then analyzed using chi-square statistical test and logistic regression statistic.Results : Through the analysis using logistic regression test, it shows that the factors affecting the medication compliance by the hypertension patients at productive age in Karangsono Village, Barat SubDistrict were working status $(p=0.000)$, family support $(p=0.001)$, and the length of time of the hypertension suffering $(p=0.016)$.Conclusion : Among those factors, working status is the factor which affects the medication compliance the most $\quad(p=0.000 ; \quad \operatorname{Exp}(B)=9.9 ; \quad 95 \% C I=2.379-36.505)$. Suggestion $:$ The hypertension medication compliance therapy needs to be improved by providing drug hypertension card independently, while for the patients who can visit the public health center, they were suggested to join the posbindu.

Keyword : Hypertension, Hypertension Medication Compliance, Hypertension Patients at Productive Age

\section{Abstrak}

Latar Belakang : Desa Karangsono merupakan desa yang memiliki presentase ketidakpatuhan paling tinggi terhadap pengobatan hipertensi dari 8 desa lainnya di wilayah kerja Puskesmas Tebon. Angka ketidakpatuhan pengobatan hipertensi usia produktif tahun 2018 di Desa Karangsono mencapai 70,7\%.Tujuan : Penelitian ini bertujuan untuk menganalisis faktor yang berpengaruh dan faktor yang paling berpengaruh terhadap kepatuhan berobat pasien hipertensi usia produktif di Desa Karangsono Kecamatan Barat Kabupaten Magetan.Metode : Jenis penelitian ini
\end{abstract}


menggunakan pendekatan case control. Jumlah sampel dalam penelitian ini yaitu 58 dengan teknik simple random sampling. Teknik analisis data menggunakan analisis chisquare dan analisis multivariat uji statistik regresi logistik.Hasil : Hasil uji regresi logistik menunjukkan ada pengaruh status pekerjaan $(p=0,000)$, dukungan keluarga $(p=0,001)$, dan lama menderita hipertensi $(p=0,016)$ terhadap kepatuhan pengobatan penderita hipertensi usia produktif di Desa Karangsono Kecamatan Barat Kabupaten Magetan. Kesimpulan : Status pekerjaan adalah faktor yang paling berpengaruh $(p=0,000 ; \operatorname{Exp}(B)=9,9 ; 95 \% C I=2,379-36,505)$. Saran : Peneliti memberikan saran yaitu untuk meningkatkan terapi kepatuhan pengobatan hipertensi perlunya kartu mandiri obat bagi pasien hipertensi serta kepada pasien hipertensi yang tidak dapat berobat ke puskesmas dapat mengikuti posbindu.

Kata Kunci : Hipertensi, Kepatuhan Pengobatan Hipertensi, Pasien Hipertensi Usia Produktif

\section{PENDAHULUAN}

Penyakit Tidak Menular (PTM) adalah penyakit yang tidak bisa menular dalam arti diderita oleh individu yang sakit dan tidak bisa berpindah ke orang lain ${ }^{1}$. Dalam kajian internasional, 68\% kematian disebabkan oleh PTM yaitu sekitar 38 juta kematian ${ }^{2}$. Secara nasional pada tahun 2018 Riset Kesehatan Dasar (Riskesdas) menunjukkan PTM meningkat pada usia remaja dan dewasa muda $^{3}$. Hal tersebutlah yang mendasari setiap warga negara usia 15 sampai 59 tahun harus mendapatkan pelayanan kesehatan sesuai standar terutama skrining faktor risiko pada usia produktif ${ }^{4}$.

Hipertensi merupakan salah satu faktor risiko penyakit kardiovaskular, jantung, gagal ginjal, dan stroke sehingga menjadi masalah utama dan secara umum diderita masyarakat. Hipertensi menjadi penyakit yang paling banyak diidap masyarakat karena kurangnya deteksi dini dan kesadaran masyarakat yang belum muncul ${ }^{5}$. Menurut American Heart Association (AHA), penduduk Amerika yang berusia diatas 20 tahun menderita hipertensi telah mencapai angka 74,5 juta jiwa. Alasan penderita hipertensi tidak minum obat berdasarkan diagnosis dokter tahun 2018 di Indonesia yaitu merasa sehat dengan presentase $(59,8 \%)$, tidak rutin ke fasyankes $(31,3 \%)$, minum obat tradisional (14,5\%), sering lupa $(11,5 \%)$, tidak mampu beli obat $(8,1 \%)$, tidak tahan efek samping $(4,5 \%)$, obat tidak ada di fasilitas pelayanan kesehatan $(2,0 \%)$, dan lainnya sebesar $12,5 \%{ }^{6}$.

Hasil Riskesdas Provinsi Jawa Timur memiliki kasus hipertensi dengan angka prevelensi hipertensi sebesar 36,3\% pada tahun 2018, jika dibandingkan dengan hasil Riskesdas tahun 2013 sebesar 26,2\% menunjukkan peningkatan angka prevalensi hipertensi ${ }^{6}$. 
Hasil pengukuran tekanan darah ditemukan kasus hipertensi di Kabupaten Magetan sebanyak 33,12\% dan masuk 9 terbesar dan tertinggi dari 38 kota atau kabupaten di Provinsi Jawa Timur (Dinas Kesehatan Provinsi Jawa Timur, 2017) ${ }^{7}$. Selama 3 tahun berturut-turut yaitu dari tahun 2016-2018 penemuan kasus hipertensi di Puskesmas Tebon belum mencapai target 100\%. Pada tahun 2018 prevalensi hipertensi di Puskesmas Tebon yaitu mencapai 41,97\% dari target $100 \%$. Berdasarkan data pelayanan penderita hipertensi usia 15-59 tahun menunjukkan prevalensi hipertensi di Puskesmas Tebon mencapai 1781 orang $(41,97 \%)$ dengan prevalensi hipertensi di Desa Karangsono yaitu $38,60 \%{ }^{8}$.

Pasien atau penderita hipertensi tidak disiplin selama pengobatan, maka hal tersebut merupakan ketidakpatuhan. Ketidakpatuhan akan berdampak pada keadaan pasien yang semakin memburuk dan menimbulkan komplikasi ${ }^{9}$. Presentase tingkat kepatuhan pasien usia 15-59 tahun (usia produktif) berdasarkan data kunjungan pasien hipertensi, presentase ketidakpatuhan pengobatan hipertensi di Puskesmas Tebon adalah 64,2\%. Desa Karangsono merupakan desa yang memiliki presentase ketidakpatuhan paling tinggi terhadap pengobatan hipertensi dari 8 desa lainnya di
Wilayah Kerja Puskesmas Tebon yaitu dari 205 pasien, $145(70,7 \%)$ pasien tidak patuh pada pengobatan hipertensi ${ }^{8}$.

\section{METODE}

Metode penelitian ini menggunakan desain penelitian survey dengan pendekatan case control, yaitu studi observasional untuk membandingkan hasil antara kelompok kasus dan kontrol dengan meneliti hubungan paparan-penyakit dari sekelompok orangorang yang berpenyakit (kasus) dan orangorang yang tidak berpenyakit (kontrol) yang telah ditentukan ${ }^{10}$.

Populasi penelitian ini adalah seluruh pasien hipertensi yang berusia 15-59 tahun berjumlah 205 pasien di Desa Karangsono, Kecamatan Barat, Kabupaten Magetan. Besar sampel diambil dengan rumus S. Lemeshow sehingga diperoleh sampel sebesar 58 yaitu 58 kasus dan 58 kontrol sesuai kriteria inklusi dan eksklusi. Kriteria inklusi sampel kelompok kasus dan kontrol yaitu bersedia menjadi responden. Kriteria eksklusi kelompok kasus yaitu pasien hipertensi usia produktif yang mengalami komplikasi dengan keadaan fisik sangat lemah. Sedangkan kriteria eksklusi kelompok kontrol yaitu pasien hipertensi usia produktif yang pindah kapitasi ke faskes lain. 
Teknik pengambilan sampel menggunakan simple random sampling yaitu setiap anggota atau unit dari populasi memiliki kesempatan yang sama untuk diseleksi sebagai sampel ${ }^{11}$. Metode pengumpul data dilakukan melalui wawancara menggunakan kuesioner yang telah diuji validitas dan reliabilitas alpha cronbach sebesar 0,60-0,70 pada bulan Februari 2020 terhadap 20 pasien hipertensi berdasarkan kasus kontrol di Desa Banjarejo karena memiliki karakteristik yang hampir sama dengan pasien hipertensi di Desa Karangsono.

Tahap analisis univariat untuk menjelaskan karakteristik tiap variabel penelitian dan analisis bivariat dengan uji statistik chisquare untuk dua variabel yang diduga berhubungan. Tahap analisis akhir yaitu dengan analisis multivariat menggunakan uji statistik regresi logistik untuk mengetahui hubungan antara satu variabel dependen dengan banyak variabel independen ${ }^{12}$.

\section{HASIL}

Berdasarkan tabel 1 terdapat 4 variabel bebas yang signifikan sekaligus menjadi kandidat dalam analisis multivariat regresi logistik. Sedangkan terdapat 2 variabel bebas yang tidak signifikan namun menjadi kandidat dalam analisis multivariat regresi logistik. Dapat diketahui bahwa hanya 3 variabel bebas yaitu status pekerjaan, lama menderita hipertensi, dan dukungan keluarga yang berpengaruh karena nilai p-value < 0,05 . Sedangkan variabel bebas yang paling berpengaruh terhadap variabel terikat yaitu status pekerjaan karena nilai $\operatorname{Exp}(B)$ semakin menjauhi angka nol dan memiliki nilai $p$ value $<0,05$ maka variabel tersebut merupakan variabel dominan.

Berikut adalah hasil analisis bivariat yang menyajikan pengujian hipotesis tersaji pada tabel 1 dibawah ini. 
DOI:

Tabel 1 Hasil Analisis Bivariat

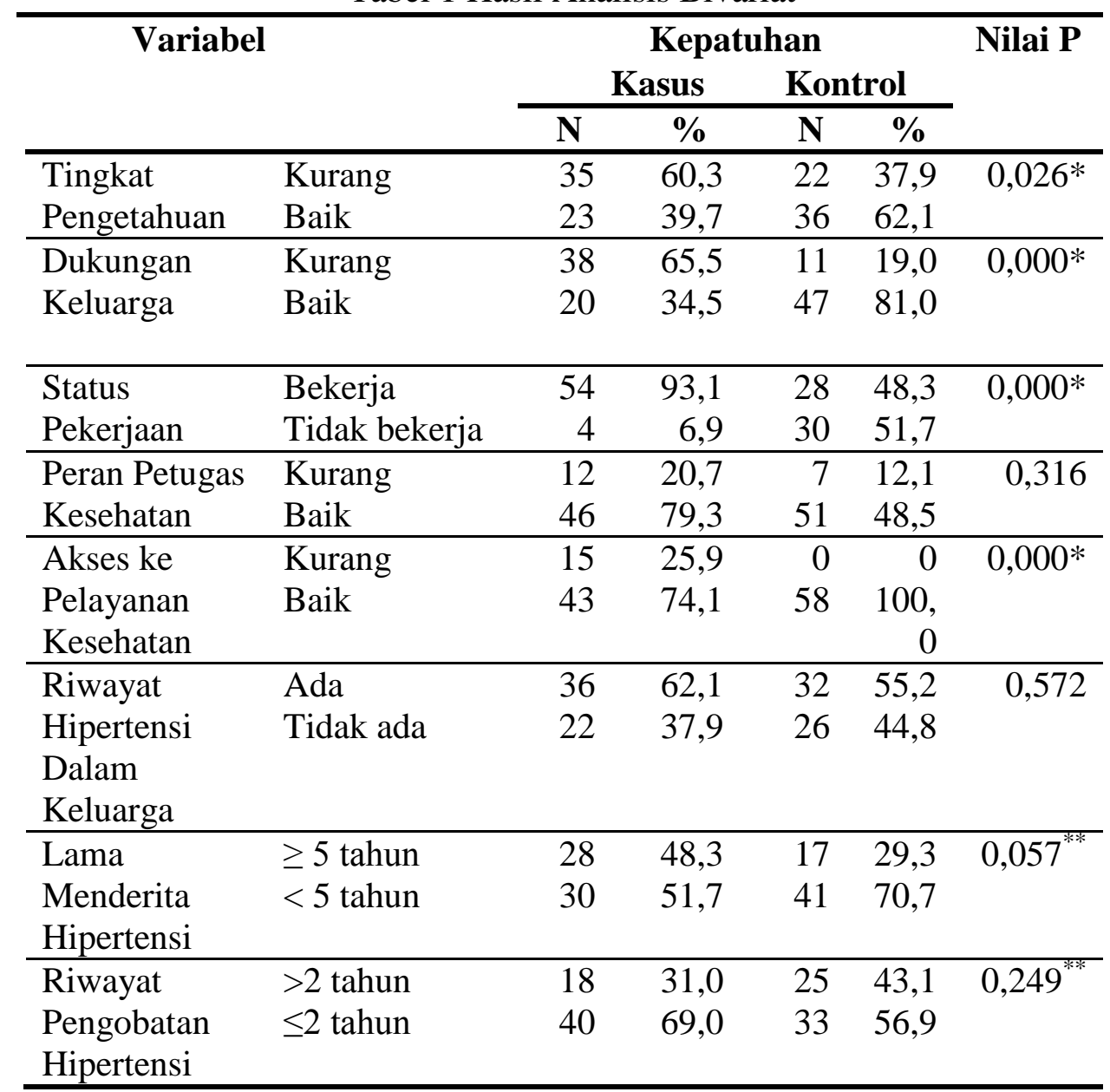

Keterangan $: *$ Signifikan $(p$ value $<0,05$ sekaligus $p$ value $<0,25, * *$ tidak signifikan $(p$ value $>0,05$ namun $p$ value $<0,25$ )

Tabel 2 Hasil Analisis Multivariat

\begin{tabular}{cccccc}
\hline No & Variabel & Nilai B & $\operatorname{Exp}(\mathbf{B})$ & $\mathbf{9 5 \%}$ CI & P-Value \\
\hline 1 & Status pekerjaan & 2,302 & 9,999 & $2,739-36,505$ & 0,000 \\
2 & Lama menderita hipertensi & 1,896 & 6,656 & $1,429-30,994$ & 0,016 \\
3 & Dukungan keluarga & 1,749 & 5,751 & $1,979-16,710$ & 0,001 \\
\hline & Konstantsa & $-2,878$ & 0,056 & & 0,000 \\
\hline
\end{tabular}

Berdasarkan analisis multivariat, variabel yang terbukti merupakan faktor risiko kepatuhan pengobatan penderita hipertensi usia produktif adalah status pekerjaan, lama menderita hipertensi, dan dukungan keluarga. Faktor yang tidak terbukti sebagai faktor risiko adalah tingkat pengetahuan tentang hipertensi, keterjangkauan akses ke pelayanan kesehatan, peran petugas kesehatan, riwayat hipertensi dalam 
keluarga, dan riwayat pengobatan hipertensi.

\section{PEMBAHASAN}

\section{Status Pekerjaan}

Berdasarkan hasil penelitian menggunakan uji regresi logistik dimana diperoleh hasil p-value $(0,000)<(0,05)$ yang menunjukkan ada pengaruh status pekerjaan terhadap kepatuhan pengobatan penderita hipertensi usia produktif di Desa Karangsono Kecamatan Barat Kabupaten Magetan. Status pekerjaan menjadi variabel yang paling berpengaruh terhadap kepatuhan pengobatan penderita hipertensi usia produktif di Desa Karangsono Kecamatan Barat Kabupaten Magetan. Hal tersebut diketahui dari hasil nilai $\operatorname{Exp}(B)$ yang paling menjauhi angka nol diantara 2 variabel lainnya pada hasil regresi logistik yaitu 9,999 .

Hasil penelitian ini diperkuat oleh teori Alan Reed, et al. (2016) yang menyatakan bahwa kebiasaan seseorang lupa untuk minum obat sebagai akibat dari kesibukan karena pekerjaan terkait ${ }^{13}$. Sejalan dengan penelitian Rano K. Sinuraya (2018) yang menunjukkan status pekerjaan berpengaruh terhadap kepatuhan dalam menjalani pengobatan hipertensi $(\mathrm{p}=0,002)^{14}$. Sesuai teori Romdlon dan Khairu (2018) bahwa individu dengan percaya diri adalah tahapan bagaimana individu tersebut dapat melakukan perilaku yang dapat menunjang kesehatannya secara berkelanjutan ${ }^{15}$.

Berdasarkan pengamatan di lapangan bahwa sebagian besar responden yang memiliki pekerjaan cenderung tidak patuh terhadap pengobatan hipertensi. Hal tersebut disebabkan oleh faktor internal sikap responden itu sendiri yaitu penilaian responden yang lebih mengutamakan pekerjaan dibandingkan harus menuju pelayanan kesehatan untuk kontrol dan minum obat tepat waktu.

Penderita hipertensi usia produktif yang bekerja seperti PNS, pedagang, dan wiraswasta harus memulai pekerjaan setiap hari sehingga tidak memiliki kesempatan untuk periksa ulang tekanan darah dan waktu untuk minum obat sesuai jadwal dikarenakan kesibukan bekerja sehingga lupa pada jadwal minum obat. Seorang wiraswasta sudah memiliki karyawan atau staf, memiliki beberapa jaringan bisnis dan sejumlah usaha yang dilakukan serta pendapatan dari berbagai sumber usaha ${ }^{16}$. Pedagang adalah orang yang berdagang, namun tidak memiliki karyawan sendiri ${ }^{17}$ Sedangkan untuk responden yang bekerja, namun masih tetap patuh dalam menjalani pengobatan hipertensi meskipun memiliki 
kesibukan, karena perkerjaan tersebut tidak terikat oleh durasi jam kerja seperti buruh/tani dan industri genteng. Industri genteng merupakan industri kecil yaitu sebuah industri yang berdiri sendiri dan tidak mempunyai kaitan dengan industri lain serta mempunyai tenaga kerja yang berjumlah 5 (lima) yang terdiri dari pekerja pemilik dan keluarga yang tidak dibayar ${ }^{18}$. Responden yang cenderung patuh terhadap pengobatan hipertensi merupakan responden yang sebagian besar tidak memiliki pekerjaan.

\section{Dukungan Keluarga}

Berdasarkan hasil penelitian menggunakan uji regresi logistik dimana diperoleh hasil $p$-value $0,001<0,05$ yang menunjukkan ada pengaruh dukungan keluarga terhadap kepatuhan pengobatan penderita hipertensi usia produktif di Desa Karangsono Kecamatan Barat Kabupaten Magetan. Sejalan dengan hasil penelitian Exa Puspita (2016) bahwa ada hubungan antara dukungan keluarga terhadap kepatuhan responden dalam menjalani pengobatan $(\mathrm{p}=0,000)^{19}$.

Menurut Harnilawati (2013) dukungan keluarga mampu membantu seseorang dalam menjalankan program kesehatan sehingga nasihat dari tenaga medis atau petugas kesehatan cenderung lebih mudah diikuti $^{20}$. Harmoko (2012) memaparkan bahwa pasien hipertensi membutuhkan dukungan dari orang-orang terdekatnya yaitu keluarga $^{21}$.

Berdasarkan pengamatan di lapangan bahwa responden dengan dukungan keluarga baik cenderung patuh pada pengobatan hipertensi karena keluarga selalu memberikan perhatian serta menunjukkan kepeduliannya seperti mengingatkan responden untuk periksa tekanan darah ke puskesmas dan minum obat sesuai jadwal, mengantar responden jika tidak dapat memeriksakan kesehatannya sendiri ke puskesmas ataupun untuk pengambilan resep obat jika habis.

Responden yang mempunyai dukungan keluarga kurang dengan keputusan patuh terhadap pengobatan hipertensi dikarenakan responden telah jelas dalam mengetahui bahaya jika tidak minum obat secara teratur karena responden mendapat penyuluhan dari petugas kesehatan sehingga mengetahui dampak atau bahaya jika tidak mematuhi pengobatan yang dijalaninya.

\section{Lama Menderita Hipertensi}

Berdasarkan hasil penelitian menggunakan uji regresi logistik dimana diperoleh hasil p-value $0,016<0,05$ yang 
menunjukkan ada pengaruh lama menderita hipertensi terhadap kepatuhan pengobatan penderita hipertensi usia produktif di Desa Karangsono Kecamatan Barat Kabupaten Magetan. Sejalan dengan penelitian Exa Puspita (2016) bahwa ada hubungan lama menderita hipertensi terhadap kepatuhan hipertensi $(\mathrm{p}=0,005)^{19}$.

Menurut Thomas \& Malcolm (2012) bahwa selain banyak pasien yang taat sesuai kontruksi dari tenaga kesehatan, namun ketidakpatuhan adalah sifat hakiki dari manusia sehingga mereka memutuskan pemakaian obat tanpa konsultasi dengan dokter atau petugas kesehatan karena bagi mereka efek samping lebih merugikan dibandingkan kondisi mereka yang sedang dalam proses diobati ${ }^{22}$.

Berdasarkan pengamatan di lapangan bahwa responden dengan lama durasi sakit $\geq 5$ tahun cenderung tidak patuh dan taat dalam mengonsumsi obat dikarenakan takut akan efek samping atau ketergantungan obat dan merasa jenuh dan putus asa karena tidak ada perubahan kondisi. Sedangkan penderita hipertensi yang menderita hipertensi $<5$ tahun lebih patuh dalam pengobatan dibandingkan penderita yang telah menderita hipertensi $\geq 5$ tahun, hal ini dikarenakan responden memiliki kesadaran dan harapan untuk sembuh.

\section{Tingkat Pengetahuan Tentang Hipertensi}

Berdasarkan hasil penelitian menyatakan bahwa tingkat pengetahuan tentang hipertensi bukan merupakan faktor risiko kepatuhan pengobatan penderita hipertensi usia produktif di Desa Karangsono Kecamatan Barat Kabupaten Magetan karena nilai $p$-value $0,622>0,05$ yang menunjukkan tidak ada pengaruh tingkat pengetahuan tentang hipertensi terhadap kepatuhan pengobatan hipertensi. Sejalan dengan hasil penelitian I Nyoman (2019) yang menunjukkan tidak ada pengaruh antara pengetahuan terhadap kepatuhan pengobatan hipertensi $(\mathrm{p}=0,789)^{23}$.

Tidak adanya pengaruh pengetahuan tentang hipertensi terhadap kepatuhan pengobatan penderita hipertensi usia produktif di Desa Karangsono Kecamatan Barat Kabupaten Magetan karena responden sebagian besar menganggap bahwa hipertensi merupakan penyakit yang bisa disembuhkan.

Berdasarkan pengamatan di lapangan adapun responden menganggap bahwa dengan patuh pada pengobatan hipertensi maka hipertensi tersebut akan sembuh, sebaliknya responden yang tidak patuh pada pengobatan hipertensi menganggap bahwa tidak masalah jika tidak rutin berobat atau 
kontrol dikarenakan hipertensi merupakan penyakit yang bisa disembuhkan dan tidak berbahaya.

\section{Keterjangkauan Akses ke Pelayanan}

\section{Kesehatan}

Berdasarkan hasil penelitian menyatakan keterjangkauan akses bukan merupakan faktor risiko kepatuhan pengobatan penderita hipertensi usia produktif di Desa Karangsono Kecamatan Barat Kabupaten Magetan karena nilai $p$-value 0,998 > 0,05 yang menunjukkan tidak ada pengaruh keterjangkauan akses ke pelayanan kesehatan terhadap kepatuhan pengobatan hipertensi. Sejalan dengan penelitian Exa Puspita (2016) bahwa tidak ada hubungan antara akses ke pelayanan kesehatan dengan kepatuhan pengobatan hipertensi $(\mathrm{p}=0,104)^{19}$.

Sesuai teori Bety dan Retno (2018) bahwa seiring perubahan pola hidup, maka terjadi perubahan dan kemajuan teknologi. Namun hal tersebut tidak dimanfaatkan dengan baik oleh masyarakat sehingga menyebabkan perilaku yang tidak positif ${ }^{24}$.

Tidak adanya pengaruh keterjangkauan akses ke pelayanan kesehatan terhadap kepatuhan pengobatan penderita hipertensi usia produktif di Desa Karangsono Kecamatan Barat Kabupaten Magetan karena seluruh responden yang patuh pada pengobatan hipertensi memiliki keterjangkauan akses yang baik ke pelayanan kesehatan.

Berdasarkan pengamatan di lapangan walaupun segala faktor eksternal / luar dari individu telah memiliki peranan yang baik, namun responden tetap tidak patuh terhadap pengobatan hipertensi. Hal tersebut dikarenakan dipengaruhi oleh faktor internal dari dalam individu itu sendiri. Adapun faktor yang paling berpengaruh yaitu status pekerjaan.

\section{Peran Petugas Kesehatan}

Berdasarkan hasil penelitian menyatakan bahwa peran petugas kesehatan bukan merupakan faktor risiko kepatuhan pengobatan penderita hipertensi usia produktif di Desa Karangsono Kecamatan Barat Kabupaten Magetan karena diperoleh hasil p-value $0,316>0,05$ yang menunjukkan tidak ada pengaruh peran petugas kesehatan terhadap kepatuhan pengobatan hipertensi. Sejalan dengan penelitian I Nyoman (2019) tidak ada pengaruh peran petugas kesehatan dengan kepatuhan berobat penderita hipertensi $(\mathrm{p}=0,251)^{23}$.

Menurut teori Sahat Saragi (2013) yang menyatakan bahwa untuk mencapai suatu 
kemitraan antara pasien dan petugas kesehatan dibutuhkan pengetahuan yang cukup dari pasien itu sendiri untuk berpartisipasi dalam menentukan penggunaan obat ${ }^{25}$.

Tidak adanya pengaruh karena responden beranggapan bahwa ketidakpahaman tersebut merupakan bagian dari peran petugas kesehatan yang masih kurang, dimana sebenarnya petugas kesehatan telah menyampaikan hal-hal tersebut.

Berdasarkan pengamatan di lapangan sebagian besar responden menyatakan bahwa peran dari petugas kesehatan memiliki peranan baik, namun responden tetap tidak patuh pada pengobatan hipertensi. Hal tersebut dikarenakan responden memutuskan untuk berhenti minum obat dan merasa takut dengan dampak jangka panjang dari minum obat secara rutin, sehingga beralih pada aktivitas-aktivitas yang harus dilakukan setiap hari seperti bekerja.

\section{Riwayat Hipertensi Dalam Keluarga}

Berdasarkan hasil penelitian menyatakan bahwa riwayat hipertensi dalam keluarga bukan merupakan faktor risiko kepatuhan pengobatan penderita hipertensi usia produktif di Desa Karangsono Kecamatan Barat Kabupaten Magetan karena nilai $p$ - value $0,572>0,05$ yang menunjukkan tidak ada pengaruh riwayat hipertensi dalam keluarga terhadap kepatuhan pengobatan hipertensi. Sejalan dengan penelitian Iche A. Liberty (2017) yang menyatakan tidak ada pengaruh riwayat hipertensi dalam keluarga terhadap kepatuhan berobat pasien hipertensi $(\mathrm{p}=0,44)^{26}$.

Menurut Martha \& Shelley (2011) bahwa penderita hipertensi dari keluarga yang memiliki riwayat hipertensi akan memiliki motivasi lebih tinggi untuk mengontrol tekanan darah sehingga meningkatkan kepatuhan terhadap konsumsi obat antihipertensi ${ }^{27}$.

Tidak ada pengaruh dikarenakan tingkat kepatuhan penderita hipertensi lebih dipengaruhi oleh kepekaan sosial. Responden tidak patuh pada pengobatan hipertensi meskipun salah satu anggota keluarganya memiliki keturunan hipertensi, karena keluarganya tidak ada yang mengingatkan untuk kontrol tekanan darah ataupun mengingatkan jadwal minum obat karena memiliki kesibukan masing-masing sehingga lupa untuk kontrol sesuai jadwal.

Berdasarkan pengamatan di lapangan responden yang memiliki riwayat hipertensi dalam keluarganya patuh pada pengobatan hipertensi dikarenakan sebagian besar responden tidak bekerja dan keluarga 
memberikan informasi serta mengingatkan responden untuk kontrol tekanan darah. Hal tersebut menunjukkan bahwa responden memiliki kepekaan sosial terhadap tanggung jawabnya dalam menjalani pengobatan hipertensi.

\section{Riwayat Pengobatan Hipertensi}

Berdasarkan hasil penelitian menyatakan bahwa riwayat pengobatan hipertensi bukan merupakan faktor risiko kepatuhan pengobatan penderita hipertensi usia produktif di Desa Karangsono Kecamatan Barat Kabupaten Magetan karena diperoleh hasil $p$-value $0,095>0,05$ yang menunjukkan tidak ada pengaruh riwayat pengobatan hipertensi terhadap kepatuhan pengobatan hipertensi.

Tidak adanya pengaruh pengobatan penderita hipertensi usia produktif di Desa Karangsono Kecamatan Barat Kabupaten Magetan dikarenakan responden yang telah menjalani pengobatan hipertensi baik selama $>2$ tahun atau $\leq 2$ tahun merasakan kekhawatiran terhadap kondisi tubuhnya akibat penyakit hipertensi yang dideritanya.

Nur Aini (2018) yang menyatakan bahwa semakin lama seseorang mengidap suatu penyakit, maka akan menjalani terapi pengobatan dalam jangka panjang atau lama, pasien akan cenderung tidak patuh karena pasien menjadi putus asa dengan terapi lama, kompleks, dan tidak menghasilkan kesembuhan ${ }^{28}$.

Berdasarkan pengamatan di lapangan bahwa responden semakin lama penderita hipertensi menjalani terapi pengobatan hipertensi, maka penderita hipertensi cenderung patuh. Dapat dilihat bahwa riwayat pengobatan hipertensi tidak berkaitan dengan lama menderita hipertensi yang artinya responden tidak merasa jenuh atau putus asa terhadap terapi yang dijalaninya, akan tetapi merasa putus asa terhadap penyakit hipertensi yang telah berlangsung lama.

\section{KESIMPULAN}

Hipertensi adalah penyakit tidak menular yang membutuhkan pengobatan hipertensi sepanjang hidupnya. Oleh karena itu membutuhkan kepatuhan dalam menjalani pengobatan hipertensi. Status pekerjaan adalah faktor yang paling mempengaruhi kepatuhan pengobatan penderita hipertensi usia produktif di Desa Karangsono Kecamatan Barat Kabupaten Magetan $(\operatorname{Exp}(B)=9,99)$. Sebaiknya bagi Institusi Kesehatan dapat memberlakukan kartu mandiri obat bagi penderita hipertensi, meningkatkan penyuluhan, melakukan 
kunjungan rumah agar dapat meningkatkan kepatuhan pengobatan hipertensi sehingga mengurangi penderita hipertensi yang memutuskan penghentian terapi pengobatan hipertensi.

\section{UCAPAN TERIMAKASIH}

Dalam menyelesaikan penelitian ini, peneliti menghadapi banyak hambatan dan kesulitan, namun berkat arahan dan bimbingan dari berbagai pihak naskah ini dapat diselesaikan, untuk itu penulis menyampaikan ucapan terima kasih kepada

1. Ibu Avicena Sakufa Marsanti, S.K.M., M.Kes, selaku Ketua Program Studi S1 Kesehatan Masyarakat dan selaku Dosen Pembimbing I STIKES Bhakti Husada Mulia Madiun yang telah memberikan bimbingan serta pengarahan dalam penyusunan penelitian ini.

2. Ibu Hanifah Ardiani, S.K.M., M.K.M, selaku Dosen Pembimbing II STIKES Bhakti Husada Mulia Madiun yang telah memberikan bimbingan serta pengarahan dalam penyusunan penelitian ini

Ibu Sukarti Amd. Keb. Selaku tenaga kesehatan di Puskesmas Tebon yang telah banyak membantu, membimbing, dan mengarahkan dalam pelaksanaan penelitian ini.

\section{DAFTAR RUJUKAN}

1. Irwan. Epidemiologi Penyakit Tidak Menular. Yogyakarta: CV. Budi Utama; 2016.

2. World Health Organization. Noncommunicable Disease [Internet]. 2018. Available from: http://www.whi.int/mediacentre/factshe ets/fs355/en/

3. Kementerian Kesehatan Republik Indonesia. Pemuda Rumuskan Keterlibatan Bermakna dalam Pembangunan Kesehatan. Biro Komunikasi dan Pelayanan Masyarakat. 2019.

4. Peraturan Menteri Kesehatan Republik Indonesia. Standar Teknis Pemenuhan Mutu Pelayanan Dasar Pada Standar Pelayanan Minimal Bidang Kesehatan. Kementerian Kesehatan Republik Indonesia. 2019.

5. Kementerian Kesehatan Republik Indonesia. Hipertensi Penyakit Paling Banyak Diidap Masyarakat. Biro Komunikasi dan Pelayanan Masyarakat. 2019.

6. Kementerian Kesehatan Republik Indonesia. Hasil Utama Riset Kesehatan Dasar. Badan Penelitian dan Pengembangan Kesehatan. 2018.

7. Dinas Kesehatan Kabupaten Magetan. Profil Kesehatan Kabupaten Magetan. Dinas Kesehatan Kabupaten Magetan. 2018.

8. Puskesmas Tebon. Data Pelayanan Kesehatan Penderita Hipertensi Usia 15-59 Tahun. Kecamatan Barat; 2018.

9. Manuntung A. Terapi Perilaku Kognitif Pada Pasien Hipertensi. Malang: 
DOI:

Wineka Media; 2018.

10. Murti B. Prinsip dan Metode Riset Epidemiologi. 4th ed. Semarang: Universitas Sebelas Maret; 2018.

11. Notoatmodjo S. Metodologi Penelitian Kesehatan. Jakarta: PT Rineka Cipta; 2018.

12. Riwidikdo H. Statistik Penelitian Kesehatan. Yogyakarta: Pustaka Rihama; 2013.

13. Alan Reed, Michael Bohlander, Nicola Wake ES. \[internet. General Defences in Criminal Law: Domestic and Comparative Perspectives. London: Routledge; 2016.

14. Sinuraya RK, Destiani DP, Puspitasari IM, Diantini A. Medication Adherence among Hypertensive Patients in Primary Healthcare in Bandung City. Indones $\mathrm{J}$ Clin Pharm [Internet]. 2018;7(2):124-33. Available from: http://jurnal.unpad.ac.id/ijcp/article/do wnload/16375/pdf

15. Romdlon F, Nishaa K. Apoteker Hebat, Terapi Taat, Pasien Sehat Panduan Simpel Mengelola Kepatuhan Terapi. Jogja: Stiletto Indie Book; 2018.

16. Putra A. Jadi Kaya Hanya dengan Modal 10 Juta: Ragam Inspirasi Bisnis dengan Modal 10 Juta. Yogyakarta: Genesis; 2018.

17. Permadi G. Pedagang Kaki Lima. 1st ed. Jakarta: Yudhistira; 2017.

18. Kimbal RW. Modal Sosial dan Ekonomi Industri Kecil Sebuah Studi Kualitatif. 1st ed. Yogyakarta: Deepublish; 2015.

19. Puspita E. Faktor-Faktor Yang Berhubungan Dengan Kepatuhan Penderita Hipertensi Dalam Menjalani
Pengobatan. Universitas Negeri Semarang. 2016.

20. Harnilawati. Konsep dan Proses Keperawatan Keluarga. Sulawesi Selatan: Pustaka As Salam; 2013.

21. Harmoko. Asuhan Keperawatan Keluarga. Jogjakarta: Pustaka Pelajar; 2012.

22. Tozer TN, Rowland M. Farmakokinetika \& Farmakodinamika. In Jakarta: EGC; 2012.

23. Purnawan IN. Kepatuhan Berobat Penderita Hipertensi Di Wilayah Kerja Puskesmas Payangan Kabupaten Gianyar. J Kesehat Terpadu [Internet]. 2019;3(1):15-21. Available from: https://jurnal.undhirabali.ac.id/index.ph p/kesehatan/article/view/709/631

24. Lakhsmi BS, Mardhiati R. Faktor Risiko Penyakit Hipertensi pada Usia Produktif [Internet]. Vol. 2, ARKAVI [Arsip Kardiovaskular Indonesia). 2017. p. 105. Available from: https://journal.uhamka.ac.id/index.php/ arkavi/article/view/2444

25. Saragi S. Panduan Penggunaan Obat. Jakarta: Rosemata Publisher; 2013.

26. Liberty IA, Pariyana, Roflin E, Waris L. Determinan Kepatuhan Berobat Pasien Hipertensi pada Fasilitas Kesehatan Tingkat I Berdasarkan anjuran Joint National. J Penelit dan Pengemb Pelayanan Kesehat [Internet]. 2017;1(1):58-65. Available from: https://pdfs.semanticscholar.org/5882/c 27d1e3daafd980a4b371e917efb22233b 4e.pdf?_ga=2.174795938.1821426305. 1576769971-1087247513.1576769971

27. Martha Craft-Rosenberg S-RP [internet]. Family Health [Internet]. 
Jurnal Kesehatan Masyarakat, Vol. 6, No. 2, 2020

DOI:

United States of America: SAGE Publications, Inc; 2011. Available from:

https://books.google.co.id/books?id=D

cLZvQIzTakC\&pg=PR4\&dq=Martha+

Craft-Rosenberg,+Shelley-

Rae+Pehler.+2011.+Family+Health. $+\mathrm{U}$

nited+States+of+America+:+SAGE+P

ublications, + Inc \&hl $=$ en $\&$ sa $=X \& v e d=0$

ahUKEwj3qa3OzIvqAhXKbX0KHbV

bCkwQ6AEIKDAA

28. Aini N. Teori Model Keperawatan.
Malang: Universitas Muhammadiyah Malang (UMM) Press; 2018. 